\title{
Critical Performative Pedagogy: Emergent Bilingual Learners \\ Challenge Local Immigration Issues
}

\author{
Ruth Harman \\ The University of Georgia \\ U. S. A. \\ Kinga Varga-Dobai \\ Georgia Gwinnett College \\ U. S. A.
}

Recent anti-immigration policies and practices in the Southeast of the United States have presented difficult challenges for newly arrived bilingual learners and their families. To validate student voices within this socio-political context, our school/university collaboration implemented an arts-based participatory approach to English Language Arts. Informed by critical discourse analysis, this paper investigates how, in the context of anti-immigration policies, a lack of social resources, and English-only instructional practices, our approach supported immigrant students in engaging agentively in social action-oriented literacy activities. Part of a larger ethnographic study, the paper focuses on a curricular project enacted in spring and fall 2010.

\author{
Arts-Based Youth Participatory Research \\ Methods \\ Literacy as a Collective Process \\ Conclusion \\ Notes \\ References \\ Transcript Conventions
}

When writing about her experiences in a social studies classroom in the United States Southeast, a bilingual learner participating in this study wrote:

Some of the instruction is so difficult for me to understand. Sometimes he (the teacher) just be speaking so fast that I don't even know what he is saying, I also don't have nobody to work with. I really don't talk to nobody in that class. (Clarita's ${ }^{1}$ free write, fall, 2010)

This experience, described by 13-year-old Clarita from El Salvador, was echoed by many of her bicultural classmates in their free writes and interview responses at a middle school in Georgia, where our larger ethnographic study was conducted over the course of three years from 2008-2011. The students 
reported often feeling marginalized and alone at school. Indeed, although Georgia has become a new destination for Latina/o newly arrived immigrant students and their families over the past 15 years, erratic approaches to TESOL and bilingual education and a very low number of Latina/o teachers and staff impact how emergent bilingual learners are positioned and taught in public school classrooms (Bohon, Macpherson, \& Atiles, 2005; Hamann \& Harklau, 2010).

Our student participants felt equally challenged outside of school, in part due to a lack of public resources in their home communities. Several students found it difficult to participate in after-school activities because the trailer parks where they lived had no access to public transportation. New anti-immigration policies and practices in 2010 and 2011 further challenged our students. For example, students expressed great concern about a ban instituted by the Georgia University System Board of Regents in October 2010, which was designed to prevent undocumented students from gaining admission to selective universities in the state regardless of high achievement records (University System of Georgia, 2010). In addition, other types of anti-immigration legislation were proposed and passed in the state legislature in recent years, including 2011's House Bill 87 which re-enforced immigrant status reviews and deportations (Georgia General Assembly, 2011). Understandably, such practices triggered high anxieties for the student participants and their home communities. Some students shared that they lived in constant fear that their parents or other community members would be taken away at night by immigration services and that they and their siblings would be placed in state custody (Field Notes, April 2010). Ironically, because of these anti-immigration policies, we could not include the teacher or the students as authors on this paper. We needed to safeguard student anonymity because some are deemed "illegal."

Participatory classroom instruction has become increasingly important within the current socio-political climate because of its potential to engage emergent bilingual students in dialogic literacy and social action practices that challenge pervasive negative immigration discourses (Cammarota \& Romero, 2011). The purpose of this paper is to investigate an arts-based participatory approach that we, the coauthors of this paper, developed with Kristen Bailey ${ }^{1}$, an experienced Euro-American ESOL teacher, her ESOL colleague, Daniel Friedman, and 11 middle school emergent bilingual learners during the spring and fall of 2010 at Chestnut Middle School in Georgia. The study is guided by the following question:

How did the arts-based participatory approach support (or not) focal students in seeing literacy as a democratic process that could be used to achieve social action? 


\section{Arts-Based Participatory Approach in Second Language Classrooms}

To grapple with current anti-bilingual and immigration discourses, educators have turned more and more to critical socio-cultural perspectives when conducting and researching second language literacy praxis with Latina/o adolescents (Martínez-Roldán \& Fránquiz, 2009). In such critical multiliteracies approaches, students and teachers are positioned as dynamic participants in an ever-evolving community of practice (Genwright, 2008; Gutierrez, 2008; Lave \& Wenger, 1991). The traditional teacher/ learner roles, where the teacher's job is to choose and direct, and the student's job is to follow and respond, are disrupted and the students become involved agentively in their language-learning processes through the research and redesign of canonical knowledge domains (Davis, 2009; Freire, 1970). Indeed, Yoon's (2010) research in a middle school ESOL classroom found that when the teacher incorporated students' sociocultural interests as a vital element in the curriculum, students became more actively engaged in classroom discourse.

In this vein, Gutierrez (2008) called for the creation of an educational third space, a purposeful shift in the typical classroom context, where voices of students, teachers, and researchers are co-articulated in multi-accentuated ways through collective literacy processes such as theater and storytelling. Davis (2009) argued for a re-envisioning of agency in second language learning as a process that supports the right of students to engage in critical inquiry that challenges normative language policies and pedagogy. In other words, the learning/ teaching cycle needs to be embedded in critical participatory approaches. Cammarota and Fine (2008) describe youth participatory action research (YPAR) as "explicitly pedagogical, with implications for education and youth development. Students study their social contexts through research and apply their knowledge to discover the contingent qualities of life" (p.6). O'Brien and Moules (2007), who developed a YPAR model in classroom research, asserted that children and adolescents must be seen as subjects and not objects in research. Their 2007 study involved the children participants in every level of the research project, including planning, delivery, and analysis.

Within this socio-cultural framework, critical performative pedagogy (CPP) is conceptualized as an arts-based participatory process that supports students in embodying and challenging socio-political issues and re-imagining social landscapes. Informed by Freire's (1970) concept of praxis, which underscores the need to use action and reflection to challenge dominant educational practices, a recursive educational use of theater, storytelling, and collective research helps participants focus on critical issues related to social equity (see Conrad, 2004; Greene, 2001; Harman \& French, 2011; Harman \& McClure, 2011). Our paper describes and analyzes how our approach supported and/or constrained 11 emergent bilingual students in agentively participating in socialaction-oriented literacy activities in an English language arts/ESOL classroom. 


\section{Methods}

Our collaborative work was conducted in the school district of Chestnutville, a small economically struggling city in Georgia with a high proportion of Latino and African American children who live under the poverty line. Chestnut Middle School provides education to approximately 600 studentsroughly 200 per grade level-and is a Title $\mathrm{I}^{2}$ school. The median income for the school district is $\$ 22,363$. In $2009-2010$, the focal year of this study, Chestnut Middle School did not make Adequate Yearly Progress (AYP) as part of the federally mandated No Child Left Behind (NCLB) requirements. The hourly English Literacy/ ESOL instructional time at Chestnut, which promoted integrated content and language literacy instruction for newly arrived students, had been reduced to 50 minutes two or three times a week in 2009-2010 (Field notes, September 2009). However, ESOL instructors and mainstream teachers were given no additional professional development time or guidance in terms of how to collaborate in mainstream courses on content and language integration. This led to some unproductive tensions among co-operating teachers and students (see Arkoudis, 2006).

In spring 2008, Ruth Harman, an Irish-born-and-raised university educator, started collaborating with Kristen Bailey, a Euro-American language teacher. Another Chesnut ESOL teacher, Daniel Friedman, also helped to support us in our daily interactions with the students during the term and became a member of the research group in fall 2010. In spring 2010, Kinga Varga-Dobai, a Hungarian-Rumanian university researcher, was invited to join the curricular initiative. Eleven female students participating in the study-nine Mexican, one Salvadoran, and one Italian/Somali-had been arbitrarily placed together in a single-sex English Literacy/ ESOL class in the fall of 2009. They had been in the U.S. educational system for various periods of time, ranging from just having arrived to four years. All struggled daily with the complex literacy demands of the mainstream curricula, inadequate time allotted to ESOL and mainstream teacher collaboration, and the increasingly hostile anti-immigration environment in the region.

Based on the needs and interests of our group of emergent bilingual learners, our action research team spent December 2009 and early January 2010 thinking of how to integrate student interests into the learning/ teaching cycle. Because our approach was participatory, the language instruction planning was contingent on decisions made by the student participants. When the class met, the students would make decisions regarding the topics/issues they wanted to explore, discuss, and write about, and possible actions they might take regarding their social interests. We would then meet to plan how to address the language needs of the students and how to scaffold and support collaborative development of the projects chosen. For example, after the students decided that they wanted to conduct research in the community and on the Internet and write 
a newsletter about their two burning issues, we decided in our meeting to (a) apprentice students into conducting and recording community interviews with family members; (b) invite an immigration expert to class to provide latest research about the legal rights of immigrants; and (c) disseminate the newsletter to families and to invited town guests at community events, such as the mayor at a Cinco de Mayo celebration. In other words, teachers and students engaged in a dialogic process where, at times, students guided the teachers' work (Freire, 1970).

A linguistic ethnographic approach was used in the collection and analysis of data related to the participatory curricular approach. That is, our research study investigated the cultural and discursive patterns and practices of the classroom community in spring 2010 and in our continued meetings with the students in the fall, when we met to prepare for a Women Studies conference (Carspecken, 1996; Fairclough, 1992, 2003). In the first phase of analysis, we conducted a broad content overview of contextual data (i.e., Chestnutville district policies, Chestnut language policies, and classroom interactions). This initial analysis helped us explore the factors that were impacting bilingual learning in classrooms and how these factors were shaped by larger social issues, such as high-stakes school reform. In other words, an overview of the local socio-political context was pivotal in investigating the ways in which we could engage with the students in the classroom and also analyze retrospectively how our approach validated their voices.

The data included field notes of all classroom activities during the 50minute class period three or four times a week during spring 2010; video and audio tapes of whole-class and small-group activities; scanned copies of focal students' writing, including district writing assessments; copies of children's literature texts and other curriculum resources; and interviews with students and teachers.

To conduct discourse analysis of the textual and classroom processes of the students and adult participants, all classroom literacy events in spring 2010 were transcribed. Systemic functional linguistics (SFL) analysis, which helps to investigate how language functions in different social contexts, was used to investigate the linguistic and rhetorical patterns in the oral and written classroom discourse (see Eggins, 2004; Halliday \& Matthiesen, 2004). Analysis included looking at use of transitivity (e.g., who is doing what to whom), appraisal (i.e., implicit and explicit evaluation) and paralinguistic cues (e.g., intonation and wait time) and how these patterns constructed particular stances toward the other participants and subject matter. In other words, analysis was used to investigate how we, the students, teacher, and researchers, related to one another and how the curricular approach validated the students in choosing, researching, and writing about local social issues (see Rymes, 2009). 


\section{Literacy as a Collective Social Process}

Second language research from a socio-cultural perspective highlights how literacy and language development of second language learners is fostered most when the curriculum incorporates students' interests, provides explicit and contingent scaffolding of difficult language and content concepts, and creates authentic audiences and purposes for writing (e.g., Gebhard, Willett, JiménezCaicedo, \& Piedra, 2010; McCarthy \& Garcia, 2005). Our analysis of the classroom interactions and student texts in this study highlighted how our approach provided participants with a space in which the learning of new concepts and academic literacy, such as expository writing, occurred within the context of reflective discussions on students' lived experience as newly-arrived immigrants. For example, reading, writing, discussions, and theatre as "repertoires of practice" (p. 152), enacted by students, contributed to community building and the development of a "collective identity" (Gutierrez, 2008, p. 153). The following sections describe how storytelling, performance, and collective research processes helped the group see literacy as collective social action.

\section{Storytelling}

Our first communal literacy event, as a research team of three women, one man and 11 girls from five different countries and language groups, was to listen to each other's family stories. Based on cultural family books they had written in a previous curricular unit, the students shared stories on one of the first days of the project in January, 2010. In turn, the adults also shared cultural narratives that highlighted their complex social identities. We integrated stories into our curricular unit because we saw stories as not only universal in the sense that they cross the boundary of cultures (Roche \& Sadowsky, 2003), but as a challenge to dominant knowledge-making processes prioritized in school. In the transcript below, Monique's story disrupts school-sanctioned stories by focusing on a dangerous border crossing (see the end of paper for transcript conventions).

128. Kristen: How do you feel right now $\downarrow$ after you've read it $\uparrow$

129. Monique: Hmm (pause) the same like as if I walked the 24 hours yesterday $\uparrow$

130. Ruth: That's a very (pause) amazing An amazing story Monique $\downarrow$

131. Kristen: ((low tone $))<$ How does anyone else feel> $\uparrow$ about it $\uparrow$ (0.1) Could you make a picture in your mind of them walking $\uparrow$

132. Ss: ((nod heads))

133. Kristen: ((nods head and looks around at students)) Wow it was powerful (pause) ((points to student)) Yes?

134. Alyssa: Scary

135. Kristen: ((nods head)) Scary $\downarrow$ (pause)

136. Monique: Yeah. <And it was amazing> cus there was a girl she was fourteen years old $\downarrow$ she was walking in the middle of the 
((gesticulates)) thi:ng $\downarrow$ she was hungry and they *just went back * ((plays with fingers of her right hand))

137. Kristen: They went ba:ck $\downarrow$

138. Monique: Yeah ((hand on chin)) And I was just like nine years old and I passed $\downarrow$ ((takes right hand off chin and starts playing with it in left))

In this event, Monique felt validated in telling her border crossing story because of the positive evaluative comments, nonverbal contextualization cues, and high interest of the other participants. In Line 137, for example, she provided an additional detail about the older girl who could not make the journey. In contrast, she constructed herself as the victorious protagonist, "And I was just nine years old and I passed." Critical race theorists highlight how such counter narratives are rarely told in institutional contexts because the "truth" is shaped in such a way that the rights of the dominant community are guaranteed through a simultaneous silencing and distortion of the experiences of subordinate groups (e.g., Delgado \& Stephanic, 2001). In our classroom, however, the relationships in the group afforded the teller and the listeners a collaborative space to extend and deepen counter narratives (Greene, 1995).

In other literacy events over the course of the spring term, such collaborative storytelling continued. In one instance, Kinga told a complex cultural story of why she had two last names and how that aspect of her identity affected her life in the United States. Our storytelling opened an alternative space where participants could share their contextualized stories without feeling shut down.

\section{Performance}

In a reflective essay about YPAR work with high school students in Tuscon, Cammarota and Romero (2011) discussed the importance of cultural organizing, which consists of encouraging students to become politically involved in their own social worlds and to think critically about the power dynamics within these contexts. In our case, we used performance to open an embodied space for re-enactment of lived experiences and critical reflection (see Harman \& French, 2011). Specifically, we used theater techniques from the Boalian Theater of the Oppressed (Boal, 1979). In forum theater, through verbal and nonverbal improvisations, participants are asked to re-imagine conflicts from their everyday lives that the group sees as oppressive and imagine new tactics of resistance (Boal, 1979, 1992). When watching the scenes that revolve around collectively chosen oppressive issues, members of the audience, or "spectactors" (Boal, 1998, p. 52), are encouraged to interrupt the scene's key moments and take on the role of the protagonist if they feel they can embody a more effective strategy.

We started the performance module by using Reader's Theater to enact a highly tense moment in a Latino/a youth novel between a Euro-American teacher 
and a Puerto Rican young woman whose name is effectively erased from the classroom discourse (Ada, 1995). After watching and discussing the scene, the students were encouraged to do free writes about particularly pressing conflicts they had encountered in their everyday school lives. In their performed reenactments of these experiences, the students depicted teachers as contributing to their sense of alienation at school. One improvisation, for example, highlighted the frustration of a newly arrived bilingual learner when trying to take an English test. She could not understand the prompt and could not get the attention of the co-operating ESOL and mainstream teachers. Spect-actors intervened in the scene and used different strategies to resolve the issue such as confronting one of the teachers directly. Another improvisation by an adult participant showed the frustration of a newly arrived immigrant at a doctor's office when she could not understand American health insurance policies.

Similar to our collective storytelling, the performance process was effective in acknowledging and incorporating student and teacher cultural funds of knowledge as valid multi-voiced contributions. As hooks (1994) states, embodied play with the teacher and student body provides a means to deconstruct how "power has been traditionally orchestrated in the classroom, denying subjectivity to some groups and according it to others" (p.139).

\section{Collective Research and Writing}

In a post-performance discussion, we asked the student and adult participants to vote on what they perceived as the most burning social issues in regards to their status as emergent bilinguals and immigrants at Chestnut and in their town. Figure 1 below shows the social issues that the group selected.

Figure 1. Voting on Social Issues

\begin{tabular}{|c|c|}
\hline $\begin{array}{l}\text { Issues Raised by Group and } \\
\text { Number of Votes for each Issue }\end{array}$ & Typed Version \\
\hline 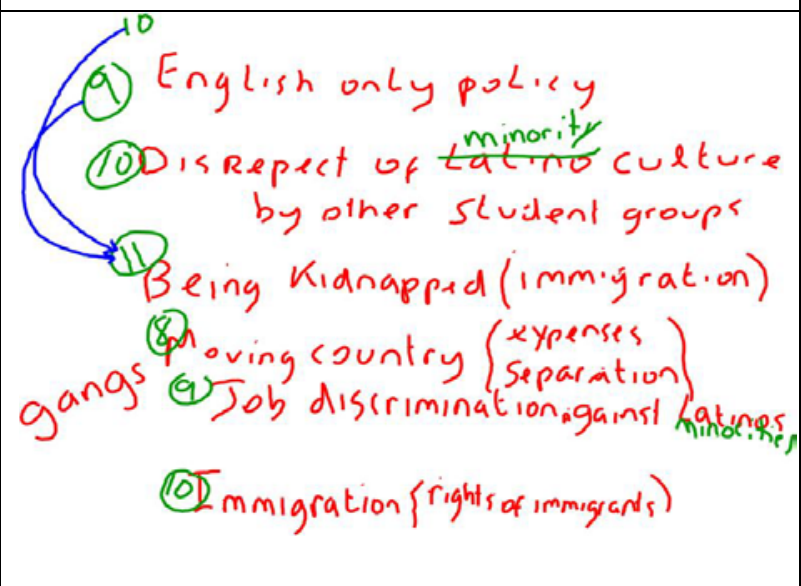 & $\begin{array}{l}9 \text { votes: English Only Policy } \\
10 \text { votes: Disrespect of minority } \\
\text { (Latino) groups by other student } \\
\text { groups } \\
11 \text { votes: Being kidnapped } \\
\text { (immigration) } \\
8 \text { votes: Moving country (expenses, } \\
\text { separation) } \\
9 \text { votes: Job discrimination against } \\
\text { Latinos (minorities) } \\
10 \text { votes: Immigration (rights of } \\
\text { immigrants) }\end{array}$ \\
\hline
\end{tabular}


As Figure 1 shows, several of the issues raised by the students highlight their sense of frustration and keen insights about the social positioning of immigrant groups in the Southeast. For example, they used the term "kidnapping" to describe the activities of the Immigration Services, a description that captures quite aptly what happened when vans would appear in the trailer parks and sweep away adults in the middle of the night. After discussing the issues in Figure 1, the students decided that the two most pressing concerns they wanted to address through social action were the following: abrupt deportation (i.e., kidnapping) of Latino community members by immigration authorities and job discrimination against ethnic minorities. The students also decided that the way to effect change was to conduct research and then write informational letters to local stakeholders, such as the town mayor and city council members. The transcript excerpt below shows their desire to discuss and address these issues:

Kristen: Does anybody have any strong feelings about what you want to do next about these issues $\uparrow$

Rosa: Write about 'em $\downarrow$

Kristen: Write about them. What'd you say $\uparrow$ Who are we going to write to $\uparrow$

Monique: Oh, we can write to that man on local TV $\downarrow$

The students also decided that the most efficient way to disseminate research was by creating a newsletter and delivering it to their families and other community members. Discourse analysis of student writing during spring 2010 revealed their strong sense of frustration and commitment in conducting their social action work. For example, the students' free writing about abrupt deportation used high appraisal (e.g., exclamation points, modality, and highly charged lexical choices) to express their discontent. Figure 2 below shows two of the girls' texts.

Figure 2: Student Writing about Issues

\section{Clarita's Free Write about Abrupt Deportation}

Abrupt deportation means that the immigration people are taking Hispanic people to where they were born. What that happens it makes me feel sad, scared and angry because I don't want $\{$ it $\}$ to happen to people that I know. Sometimes the immigration people take the parents and leave the children

\section{Rosa's Free Write about Abrupt} Deportation

I feel bad of abrupt deportation because it is happening at Walmart and I don't like when they say the police well not the police but the immigr. was at WalMart. And I don't want \{I want $\}$ to live in GA because is very beautiful and because we can send money to my family my parents and uncle got a job. but I feel very sad. Sometimes I ask myself why does immigration deport the Hispanic people but I feel very sad 


\begin{tabular}{|c|c|}
\hline $\begin{array}{l}\text { Analysis: Lexical choices } \\
\text { highlight the negative } \\
\text { evaluative stance of writer (take } \\
\text { them to where they were born; } \\
\text { leave the children) and explicit } \\
\text { expression of emotion (sad, } \\
\text { scared, angry) }\end{array}$ & $\begin{array}{l}\text { Analysis: Use of repetition (bad/sad) and } \\
\text { expressions of negative emotion (I don't } \\
\text { like, I don't want, I ask myself why) to } \\
\text { express opinion about the issue. } \\
\text { Heteroglossic inclusion of family members } \\
\text { also in the text (my family, my parents, and } \\
\text { my uncle) }\end{array}$ \\
\hline
\end{tabular}

As highlighted in Figure 2, Rosa's text reflects her frustration and also her strong sense of identity as a family and community member in her reaction to the issue of abrupt deportation. Her text also shows the ambivalence she felt about Georgia: it provided her family with job opportunities and money they could send home, but at the same time the anti-immigration practices against Latinos made her feel "very sad." In a different way, Clarita expressed her concern not only by using explicit expressions of emotion but also by her highly charged lexical choices: her ending sentence is especially powerful as it highlights the harsh reality that children are separated from parents during deportation proceedings.

Impassioned by their burning issues, the students also integrated what they learned from their Internet research and from community interviews in their expository writing for the newsletter. In other words, they became invested in using the collective literacy process as intertextual resources for their writing (see Harman, in press). Clarita, for example, took notes during the immigration guest lecture and used what she perceived as its most important elements to highlight in her own writing that, legally and socially, documented and undocumented Mexicans should be treated no differently from other cultural groups in the nation. Rosa wrote about the discrimination experienced by Latinos in the job market and included information from her interview with a community member.

Studies show that three in every ten Hispanic workers feel they have been discriminated! A woman that was working in a poultry plant got discriminated because she was not a citizen. She went to the manager and the manager told her that it doesn't matter because she was not a citizen. She felt discriminated.

Another student's narrative explored the definition of abrupt deportation by providing powerful testimony of the havoc it had wreaked on her uncle who disappeared without trace into the black hole of deportation for two years. Other students chose to write about social services provided to Latina/o and other immigrant groups in the area and about national statistics on the immigrant demographics of the United States, researching facts that they accessed through interviews with the guest lecturer and through Internet searches conducted with the adult members of the group.

Overall, the social action process galvanized students to research and rewrite drafts of their texts when they perceived their writing as having relevance to their community lives and when they knew that their writings would be read by their families and other community members. Recent research by the 
professional development initiative, the ACCELA Alliance, also showed similar findings about the higher investment level of language learners when engaged in local social action (see Gebhard, Harman \& Seger, 2007; Gebhard, Shin, \& Seger, 2011).

\section{Dissemination and Social Action}

Through the collective literacy process, the students and adult members of the group also developed a shared interest in disseminating and challenging the issues that the group had identified as most important to it. For example, together we decided to create a collective poem about the social issues and perform it at a school celebration on Cinco de Mayo, when we also distributed the newsletter to the school and home communities of the students and teachers. The final lines of the poem, which deals with the new anti-immigration practices in Arizona and Georgia, were as follows:

No more haters!

No more discrimination.

No more broken-up families.

Before I felt confused, but now I'm strong.

I feel powerless alone but stronger as a group.

Together we are strong. We must help each other.

The parallel structures in this poem (e.g., broken-up families versus stronger as a group) highlight how the emergent bilingual students experienced isolation and despair about the anti-immigrant and language policies in the state but also solidarity through collective social action.

To maintain the momentum of the group and to ensure that the girls would persist in seeing themselves as researchers of their own issues, we asked them if they would be interested in participating in a local Women's Studies conference in fall 2010, where they could present an explanation of the communal process of identifying and writing about local social issues in the context of an English Literacy/ ESOL curriculum. The girls who still remained at Chestnut-some had left for high school-all wanted to participate. They gave up several lunch breaks and ate with the adult participants in September and October 2010, to prepare for the event. Based on her previous theater work with children and adults, Ruth wrote a first draft of a performance ethnographic script, which Kristen, Kinga, and the girls edited. The short scene, performed in Spanish and English, depicted the pain that the home communities of the girls experienced very regularly when "La Migra" invaded their homes, but it also represented the collective power they experienced after working together as a group (see Conrad, 2004 for similar approach). The girls also presented at a university colloquium in spring 2011. 
Overall, the participatory arts-based approach encouraged the study's 11 student participants and three adults to engage with literacy in powerfully collaborative ways. Although the power relations between adults and students were not disrupted (as evidenced by the fact that two of the adults are writing this paper), all of us felt a strong momentum to remain connected and active as a social action group. In addition, the keen insight and very dynamic sense of community that the students shared often positioned us, the adult participants, as learners (Freire, 1970). As middle-class White educators, although two of us were immigrants, none of us had ever faced the high levels of job discrimination or fear of deportation that the students knew about first hand or through their community. However, through our collaboration with the students, our understanding and sense of indignation about these issues were heightened. In other words, the students were and still are our teachers.

\section{Conclusion}

Despite the promising outcomes in terms of how our approach invited student participation in ways that positioned them as agentive members of their communities, our research was limited by logistical issues such as lack of time, transportation, sporadic school attendance, and other issues that were shaped by the glaring absence of a strong institutional infrastructure to support the students and their families outside of school in this region of the United States Southeast (Wortham, Murillo, \& Hamann, 2002). For example, our collaborative work needed to be confined to very short instruction slots of time or lunch time periods.

In addition, a limitation in our approach was the lack of participation by adult insider community members in the research team. All adult members of the team were White middle-class educators. Although two of us were immigrants and one was an English Learner, none of us lived in the home communities of the students, nor did we speak Spanish or Italian with high levels of proficiency. Unfortunately, in the Chestnutville area, recruiting community members to become involved would have been very difficult since the families often worked long hours and also lived far from the school. In addition, there were few Latina/o students working as research assistants in the university community. As Colomer and Harklau (2009) point out, this lack points to the dire need in the region for more bilingual and bicultural educators who can work effectively with immigrant students and families.

Our social identities (adult outsiders/ university researchers/ ESOL teachers) also played a large part in determining the power relationships in our group. Although adults and students worked together as a team, the adult ESOL and university teachers determined the language teaching process. In preparing for two conferences with the girls in 2010 and 2011, Ruth wrote the performance script. This highlighted a lack of power distribution among students and adults. This type of power asymmetry was heightened by the fact that our official role in 
the ESOL classroom was to support academic language and literacy development in English. This ideological expectation foregrounds English as the exclusive or at least predominant language of instruction and effectively erases student home languages from the curriculum.

Overall, although some elements in the approach were problematic, the incorporation of student voices and the inclusion of authentic purpose and audience for writing in this praxis-oriented pedagogy (Cammarota \& Romero, 2011) encouraged the students to use a range of genres in their oral and written discourse (e.g., storytelling, dramatic replay, discussion, and newsletter composition) to communicate their emotions and research about immigration issues. Some key elements of our approach that could be used by other multicultural second language educators in context-specific ways are the following:

Collaborative Literacy Practices: Our approach provided student participants with a space in which the learning of new concepts and literacy skills, such as expository writing, occurred within the context of reflective discussions on their lived experience as newly arrived immigrants. Participants used a range of genres in their oral and written discourse (e.g., storytelling, dramatic replay, discussion, and newsletter writing) to communicate their emotions and research about immigration issues. In addition, the group became more tightly affiliated through the constant retelling of shared experiences within the classroom, when visitors came to the classroom, and through shared activities that occurred outside of the classroom, such as conference presentations.

Research and Social Action: The incorporation of student voices through performance and storytelling galvanized students into seeing literacy as a material semiotic process with authentic audience and purpose. The student process also supported adult participants in learning more about and challenging the local community issues. Indeed, some of the adult participants are now involved in activist local work with Latino families to fight against issues such as the ban on undocumented students from entering higher ranked universities in Georgia.

Our curricular approach is informed by second language research that stresses the importance of incorporating students' socio-cultural interests into the curriculum as well as providing them with carefully crafted language scaffolding (e.g., George, Raphael, \& Florio-Ruane, 2003; Yoon, 2010). Our approach also is an embryonic use of the critical socio-cultural approach suggested by Gutierrez (2008). However, our work needs to be expanded to include multicultural community involvement and realized through more extended periods of time with students and their families. We also need to constantly reflect on our social identities (race, ethnicity, and class) that shape the power dynamics in our collaboration with students (Ladson-Billings, 2000).

Our arts-based participatory approach, in the context of multicultural and second language education, aims to support students and teachers in grappling with local power relations which are dialectally connected to broader institutional 
and societal practices that marginalize students and teachers based on race, class, gender, and other markers of difference (Nieto \& Bode, 2008). Despite the challenges we have described, our hope is that this embodied practice, the imaginative use of theater, collective research, and storytelling, can lead to a heightened awareness of literacy as a collective and social action process among teachers, researchers, and emergent bilingual students, and that this collective process can be applied and researched more often as an instructional practice that better positions second language students as agentive members in the classroom in support of their academic literacy development.

\section{Notes}

1. All names of school teachers, students and place names are pseudonyms.

2. Title I, part of the Elementary and Secondary Education Act of 1965, distributes funds to schools with a high percentage of low-income families.

\section{References}

Ada, A. F. (1995). My name is Maria Isabel. New York, NY: Atheneum Books for Young Readers.

Arkoudis, S. (2006) Negotiating the rough ground between ESL and mainstream teachers. International Journal of Bilingual Education and Bilingualism, 9(4), 415-433.

Boal, A. (1979). Theater of the oppressed. New York: Theater Communications Group.

Boal, A. (1992). Games for actors and non-actors. (A. Jackson, Trans.). London, UK: Routledge.

Boal, A. (1998). Legislative theatre: Using performance to make politics (A. Jackson, trans.). London, UK: Routledge.

Bohon, S. A., Macpherson, H., \& Atiles, J. H. (2005). Educational barriers for new Latinos in Georgia. Journal of Latinos and Education, 41, 43-58.

Cammarota, J., \& Romero, A. (2011). Participatory action research for high school students: transforming policy, practice, and the personal with social justice education. Educational Policy, 25(3), 488-506.

Cammarota, J., \& Fine, M. (Eds.). (2008). Revolutionizing education: Youth participatory action research in motion. New York, NY: Routledge.

Carspecken, P. F. (1996). Critical ethnography in educational research: A theoretical and practical guide. New York, NY: Routledge. 
Colomer, S. E., \& Harklau, L. (2009). Spanish teachers as impromptu translators and liaisons in new Latino communities. Foreign Language Annals, 42(4), 658-672.

Conrad, D. (2004). Exploring risky youth experiences: Popular theatre as a participatory, performative research method. International Journal of Qualitative Methods, 3(1) Article 2. Retrieved from http://www.ualberta.ca/ -iiqm/backissues/3_1/pdf/conrad.pdf

Davis, K. (2009). Agentive youth research: Towards individual, collective, and policy transformations. In T.G. Wiley, J. S. Lee, \& R. Rumbergers (Eds.) The education of language minority immigrants in the USA (pp. 203-239). London, UK: Multilingual Matters.

Delgado, R., \& Stefancic, J. (2001). Critical race theory: An introduction. New York: New York University Press.

Eggins, S. (2004). An introduction to systemic functional grammar (2nd ed.). New York, NY: Continuum.

Fairclough, N. (1992). Discourse and social change. Cambridge, UK: Polity Press.

Fairclough, N. (2003). Analyzing discourse: Textual analysis for social research. New York, NY: Routledge.

Freire, P. (1970). Pedagogy of the oppressed. New York, NY: Continuum.

Gebhard, M., Harman, R., \& Seger, W. (2007). Reclaiming recess in urban schools: The potential of systemic functional linguistics for ELLs and their teachers. Language Arts, 84(5), 419-430.

Gebhard, M., Willett, J., Jimenez, J., Piedra, A. (2010). Systemic functional linguistics, teachers' professional development, and ELLs' academic literacy practices. In T. Lucas (Ed.), Preparing all teachers to teach English language learners (pp. 91-110). Mahwah, NJ: Erlbaum/Taylor \& Francis.

Gebhard, M., Shin, D., \& Seger, W. (2011). Blogging and emergent L2 literacy development in an urban elementary school: A functional perspective. CALICO Journal, 28(2), 278-307.

George, M. A., Raphael, T. E., \& Florio-Ruane, S. (2003). Connecting children, culture, curriculum, \& text. In G. Garcia (Ed.), English learners: Reaching the highest level of English literacy (pp. 308-332). Newark, DE: International Reading Association.

Georgia General Assembly (2011). Retrieved from http://www1.legis.ga.gov/ legis/2011_12/sum/hb87.htm

Ginwright, S. (2008) Collective radical imagination: Youth participatory action research and the art of emancipator knowledge. In J. Cammarota \& M. Fine (Eds.). Revolutionizing education: Youth participatory action research in motion (pp.13-22). New York, NY: Routledge. 
Greene, M. (1995). Releasing the imagination. San Francisco, CA: Jossey Bass Publisher.

Greene, M. (2001). Variations on a blue guitar: The Lincoln Center Institute lectures on aesthetic education. New York, NY: Teachers College Press.

Gutierrez, K. D. (2008). Developing a sociocritical literacy in the third space. Reading Research Quarterly, 43(2), 148-164.

Halliday, M., \& Matthiesen, C. (2004). An introduction to functional grammar. London, UK: Arnold.

Hamann, E., \& Harklau, L. (2010) Education in the new Latino diaspora. In Murillo, E. (Ed.), Handbook of Latinos and education: Research, theory, and practice (pp. 157-169). Mahwah, NJ: Lawrence Erlbaum Routledge.

Harman, R., \& McClure, G. (2011). All the school's a stage: Critical performative pedagogy in urban teacher education. Equity \& Excellence in Education. 44(3), 379-402

Harman, R., with French, K. (2011). Critical performative pedagogy and urban teacher education: Voices from the field? Play and Culture Series, 11, 84104.

Harman, R. (in press). Intertextuality in genre-register pedagogies: Building the field in L2 fifth grade literary writing. Journal of Second Language Writing.

hooks, bell.(1994).Teaching to transgress: Education as the practice of freedom. New York, NY: Routledge.

Ladson-Billings, G. (2000). Racialized discourses and ethnic epistemologies. In N. Denzin \& Y. Lincoln (Eds.). Handbook of Qualitative Research (2nd ed., pp. 398-432). Thousand Oaks, CA: Sage.

Lave, J., \& Wenger, E. (1991). Situated learning: Legitimate peripheral participation. Cambridge, UK: Cambridge University Press.

Martínez-Roldán, C., \& Fránquiz, M.E. (2009). Latina/o youth literacies: Hidden funds of knowledge. In L. Christenbury, R. Bomer, \& P. Smagorinsky (Eds.). Handbook of Adolescent Literacy Research (pp. 323-342). New York, NY: Guilford Press.

McCarthey, S. J., \& Garcia, G.E. (2005). English language learners' writing practices and attitudes. Written Communication, 22(1), 36-75.

Nieto, S., \& Bode, P. (2008). Affirming diversity: The sociopolitical context of multicultural education (5th ed.). New York, NY: Allyn \& Bacon.

O'Brien, N., \& Moules, T. (2007). So round the spiral again: A reflective participatory research project with children and young people. Educational Action Research, 15(3), 385-402.

Roche, L. \& Sadowsky, J. (2003). The power of stories (I): A discussion of why stories are powerful. IJITM 2(4), 377-388. 
Rymes, B. (2009). Classroom discourse analysis: A tool for critical reflection. Cresskill, NJ: Hampton Press.

University System of Georgia (2010). Retrieved from http://www.usg.edu/news/ release/regents_adopt_new_policies_on_undocumented_students/

Wortham, S., Murillo, E., \& Hamann, T. (2002). (Eds.) Education in the new Latino diaspora: Policy and the politics of identity. Westport, CT: Ablex.

Yoon, B. (2010). Meeting the cultural and social needs of English-language learners: A middle school ESL teacher's practice. Teacher Education and Practice, 23(1), 31-43.

\section{Appendix A}

\section{Key of Transcript Conventions}

$=\quad$ Latching (response immediately after)

[] Simultaneous (overlapping speech)

(.) Short pause

$<\quad$ Speeding up

$>\quad$ Slowing down

Text Emphasis

CAPS Screaming (volume)

Bold Loud voice

"pst* Quiet voice

(...) Inaudible

(( )) Gestures/other noises

$\downarrow \quad$ Lowered pitch

$\uparrow \quad$ Raised pitch

No: Elongated vowel 